\title{
17 Elite Compromise as a Mode of Institutional Change: The United States and Norway Compared
}

The history of democracy may be read as a story of tensions between government by the people and governance by political and social elites. Over the last 200 years, from the emergence of modern ideas of democracy, these tensions have taken different forms, and they are still felt in the $21^{\text {st }}$ century. Intuitively, it is not surprising that elite groups fear that their position is threatened and defy popular demands for influence; and likewise that subordinate groups challenge elite power. In more principled terms, the problem was stated in classical elite theory (Bachrach, 1969). In opposition to socialist ideals of equality, Vilfredo Pareto (1991) argued for the inevitability of elite governance, disparaging democracy as wishful thinking. Gaetano Mosca (1939) regarded representative institutions as a necessary supplement to secure elite supremacy. Their theoretical argumentation found support in Robert Michels's detailed study of the German Social Democratic Party (2001), which revealed an 'iron law of oligarchy' even within an organization devoted to diminishing inequalities.

In later elite theory the relationship between democracy and elites has been modified and restated (Field \& Higley, 1980; Higley \& Burton, 2006). This alternative version shares with classical elite theory the assumption of the necessity of elite formation in any large-scale society; it follows from the unavoidability of large-scale organization for social and political governance and the ensuing need for leadership. But it differs from the classical view by turning the relationship between elites and democracy on its head, positing that compromises between competing elite groups is a necessary condition for democracy to emerge.

In Elite Foundations of Liberal Democracy John Higley and Michael Burton (2006) give a broad description of the institutionalization of compromises between elites as the initial steps to democracy in a large set of societies. If elite groups find it in their interest to institutionalize frameworks for the regulation of conflict between them, in other words to 'agree to disagree', it may initiate a process towards democratic governance. Taken as a systematic emphasis on elites and group action, this conception may be criticized for lack of nuances and for overlooking crucial elements in the historical context. Prominent discussions of the establishment of democracy have introduced a large set of structural factors as explananda of the emergence of democracy: industrialization (Lipset, 1959), economic development (Dahl, 1999), the presence of a bourgeoisie (Moore, 1966), level of education (Dahl, 1989), social capital (Putnam, 1993) and social movements (O’Donnell \& Schmitter, 1986). Samuel Huntington (1991) even 'lists twenty-seven additional variables that affect the causal chain' behind the introduction of democracy in addition to elite action (Higley \& Burton, 2006, p. 3). 
Higley and Burton defend their lean conception of elite action against the introduction of excessive numbers of variables in historical analysis to achieve saturated explanations. Simple models carry more explanatory power; they yield salient insights by virtue of their simplicity. Emphasizing elite action does not deny the role of mass movements in the formation of democracy, but powerful mass movements are also dependent on their own elite representation. At the end of the day, forging viable compromises and agreements is impossible without intervention by elite groups. Yet, important as initial compromises may be as openings for democracy, over time they cannot remain stable. There is of course no lack of examples of the instability and decay of democracies (Higley \& Burton, 2006, passim). At the same time, the changes in constitutive compromises are just as important in societies which have remained democratic and even those that have deepened democracy over time. This is the main topic to be discussed in the following while remaining within the lean conception of elite action.

This presupposes broadening the conception of elite compromise beyond the constitutive compromise envisaged by Higley and Burton by redefining it as a sequence of the institutionalization of compromises. These sequences take different trajectories in different societies. The reformulation may be made in three steps. The first is by going into the dynamic nature of initial elite compromises. To what extent are they able to remain stable, given a specific set of institutional patterns? Alternatively, how can they be combined with the necessary flexibility? The second is by broadening the concept of compromise to include the notion of subsequent, more specific secondary elite compromises. Ongoing social change implies the differentiation of social spheres and hence the reconstitution of elite groups in their specific fields of interaction. When new compromises are settled within these spheres, they may have aggregate effects on constitutive compromises. How, and to what extent, are they influenced, reinforced or changed by secondary compromises? Third, the dynamics of elite compromises should be described and reinterpreted within an institutional framework. To be sustainable, compromises must be institutionalized. Yet, institutions are not deterministic. Tensions emerge among them, and they become fields of competition, reinterpretation and power struggles; thereby they are in constant, albeit slow, change. Given different institutional configurations, these processes follow specific patterns in different societies; comparing trajectories opens up for the adjustment of existing theories of institutional change.

The fruitfulness of these assumptions is assessed by comparing central points in the political history of two countries, the United States and Norway. These two societies are strikingly different in many, some would even say most, respects. Size is an obvious dissimilarity, but far from the only one. The United States was from the outset an immigrant society in territorial expansion, for a long time with an underdeveloped state bureaucracy (Fukuyama, 2014). Slavery was a constituent part of the US for 80 years. Norway had from the beginning of state sovereignty fixed 
borders and a relatively well-established state apparatus. The country had no nobility, and a high number of independent farmers.

Nevertheless, there are decisive parallels in the initial stages preceding democracy and democratic institutions that motivate a more extensive comparison. The two countries took the first steps on the trajectory to democracy some years before and after 1800, when they both gained independence from a colonial power. As part of the liberation both adopted a constitution, very radical for its time; presently they have the world's two oldest constitutions which are still in existence. At later stages, both countries experienced the forceful processes of modernization and democratization. In several areas, the United States has also given important inspiration to Norwegian politics. This gives a unique opportunity to sketch and compare long-term social and political developments in the light of elite theory.

The analytic strategy lies in the comparison of two societies, which initially had some important similar traits but over time developed in different directions. The combination of similar and dissimilar traits in the two cases, both highly significant, invites neither a most similar nor a most dissimilar methodological approach (Ragin, 1987). The comparison cannot assess the effects of specific variables but can give a rich description of different social and political trajectories shaped by the institutional requirements of modernization and democratization. In the analysis of these developments, the notion of elite compromise serves as a sensitizing concept. The empirical material is mostly limited to standard secondary sources; the gist is in the comparison, making the two cases illuminate each other. Whenever relevant, references are also made to the Open Access contributions to the two additional volumes in the series on institutional change in the Nordic area (Engelstad \& Hagelund, 2015; Engelstad, Larsen, Rogstad, \& Steen-Johnsen, 2017).

The exposition starts with brief accounts of elite theory and theory of institutional change. Next, the dynamics in the original elite compromises are outlined, followed by a discussion of the different shapes of secondary elite compromises. The concluding sections summarize the observed differences in trajectories of institutional change, and finally, challenges to democracy in the two societies are sketched. The ideas presented draw on earlier work connected to a large-scale elite study in Norway but are limited to this country only (Gulbrandsen et al., 2002; Engelstad, Gulbrandsen, \& Østerud, 1999). Making the comparison with the United States develops a more comprehensive picture of the variation in elite compromises and their possible role in the maintenance of democracy.

\subsection{Elites and Compromises}

An early version of the institutionalization of elite interaction in economic life was developed by Ralf Dahrendorf in Class and Class Conflict in Industrial Society (1959). In modern democracies class conflict between labour and capital along the lines 
described by Marx has not vanished but is modified and tempered by a series of institutional restrictions. Building on traditional elite theory, Dahrendorf pointed out that in the long run it is in the interest of both parties to institutionalize their relationship by setting up frameworks for regularized negotiation. Thereby class antagonisms are translated into power differentials between elite groups, opening up for the study of elite relations in an institutional perspective.

Higley and Burton (2006) take a related stance in their large-scale survey of successful and failed attempts at instituting elite compromises at the societal level. Elite relations fall into one of three main types: elites may either (i) be divided into hostile camps, or (ii) they may be coercively united under a strict ideological umbrella or (iii) they may coexist in a consensual relationship with moderate conflicts that do not threaten their coherence (Higley \& Burton, 2006, p. 14). Only if elites are consensual in the latter meaning does democracy become possible. The compromise of elites on a modus vivendi despite extensive social conflicts implies agreement on a political order and some sort of constitution, be it formal or informal, including rules for interaction and binding decisions. Elite compromises do not abolish political and social conflicts; rather, they channel and regulate them. In addition, elites must be able to mobilize support from ordinary citizens; thus each elite is acting along two axes - on their relationship to other elites and their relationship to their rank-and-file constituency. The former implies reciprocal understanding and bargaining, and the latter rests on various degrees of voluntary compliance and mobilization.

Which groups, then, constitute the elites? The concept of 'elite' has many connotations: in the present chapter it designates the persons who fill powerful positions in high politics and at the summit of large organizations and thereby influence political outcomes (Field \& Higley, 1980; Gulbrandsen et al., 2002). Elite composition is altered over time due to social differentiation and cultural and economic change. The elites that entered into the original settlements in the United States and Norway were few and relatively undifferentiated (Frydenlund, 2014). Over time they have differentiated and been complemented by new elite groups, while other groups have lost power over the long run. In modern societies, elites comprise a broad set of groups:

not only the familiar 'power elite' triumvirate of top business, government and military leaders, but also top position holders in parties, professional associations, trade unions, media, interest groups, religious groups, and ... socio-political movements. ... The ability to affect these [political] outcomes regularly and substantially distinguishes elites from all other people in a society. (Higley \& Burton, 2006, p. 7)

The power of elites has a specific character, delimited by extensive rules and regulations pertaining to their institutional field as well as the specificity of their sources of power, often termed asset specificity (Williamson, 1975). The varying modes and forms of their interaction constitute the elite structure in different societies. 
The question arises as to how, after the original elite compromise, various elite interests are integrated and upheld. Given support for compromises and the political values they embody, actors assume that others will also live up to shared values, which shapes their own long-term interests. By a logic of path dependency (Pierson, 2004), reciprocity engenders trust. But even if informal communication and political values are crucial for regulating power relations, they are too imprecise to constitute a persistent basis for reciprocal understanding between groups. To be sufficiently robust, they must to be anchored in institutionalized agreements. This is not limited to a formal constitution but instead embraces the broader field of 'constitutional culture' (Smith, 2003) - that is, the combination of constitutional texts, their institutionalized interpretation and political practice.

Even if elite compromises shape the rules of the game, and the actors in the next round are conditioned by these formal and informal rules, the stability is only apparent. Institutions are constantly targets of power struggles and efforts to alter rules. In addition to changes in external factors, new social groups arise, interpretations of norms and values do not remain constant and patterns of power resources are in flux, creating changes in citizen rights, voting rights and in the relationships between political institutions. One possible source of stabilization is that the original compromise is supplemented by secondary elite compromises (Engelstad et al., 1999; Gulbrandsen et al., 2002) between specific elite groups in restricted social spheres, such as working life, the welfare state or culture. These compromises do not concern basic citizen rights but rather regulate and shape power relations within the given sector and modify the frames of debate, competition and conflict, while at the same time they become relevant to specific policy fields at the national level.

\subsection{Institutionalization and Institutional Change}

Crudely, institutions may be described as relatively stable macro regulations in the form of norms, legislation and large-scale agreements, shaping the behaviour of individuals, groups and organizations (Thelen, 2004; Mahoney \& Thelen, 2010; Engelstad \& Hagelund, 2015). They have both formal and informal aspects (Scott, 2008). A conception of institutional structure and stability, indirectly related to that of Dahrendorf, was elaborated by Peter Hall and David Soskice in Varieties of Capitalism (2001). They focus on the labour-capital relationship via its institutional surroundings - most prominently education, vocational training and labour market policies. A salient point is that these institutions are bundled in systematic ways, also with other institutions, such as the juridical and political. The shape of bundles varies across countries but is assumed to be relatively stable because each has specific productivity advantages. On this basis, modern capitalist societies are classified into two main types: Liberal Market Economies and Coordinated Market Economies. The United States and Norway represent extreme cases of the two types; in this respect 
they represent fruitful cases for comparison. The theory of varieties of capitalism is criticized for being too static, disregarding inconsistencies and tensions within and between institutions which engender constant change (Thelen, 2012). However, the concept of bundling as such is not necessarily static; it may also refer to central conditions shaping modes of institutional change.

Basically, theories of institutional change fall into three types: one focusing on path dependency and the sudden ruptures of given patterns, one emphasizing the long-term aggregate effects of many small elements, and a third version underscoring the salience of ideas and ideology in institutional change. Even though these theories are often presented as alternatives, they are not incompatible and are better regarded as complementary perspectives (Thelen, 1999; Engelstad \& Hagelund, 2015). The basic idea of path dependency assumes that stability is a normal condition, reinforced by actors taking given social patterns for granted and adjusting their actions to them; hence in the next round it becomes more costly to break away from it. Changes occur when external shocks engender crises, opening a window of opportunity for a new policy. Paul Pierson (2004) broadened the theory, insisting on the salience of timing and sequencing - how options in one given situation open up for or close to options in the future. The theory of aggregate effects is based on the assumption that a large number of actions in micro produce changes in institutions over time. Kathleen Thelen has pointed to several mechanisms of gradual institutional change: layering, displacement, conversion and drift (Thelen, 2004; Mahoney \& Thelen, 2010). In contrast to path dependency theory, aggregated processes elicit changes endogenously; but in the long run they, too, may contribute to a large-scale crisis, opening a window of opportunity. Both these conceptions take a somewhat narrow view of political processes and the ideas underlying them. As underscored by Vivien Schmidt (2009), political ideas are salient for understanding institutional change. Thus, theories of institutional change point to possible combinations of external shocks, internal long-term micro processes and ideology and political values as sources for changes to elite compromises.

\subsection{United States and Norway: Establishment of Primary Elite Compromises}

The constitutions of the United States and Norway, dating from 1787 and 1814, materialized in the wake of secession from a colonial power, Britain and Denmark, respectively. This is one reason why they hold a privileged position in each country's political history. At the time of their adoption, both constitutions represented radical steps in the direction of democracy, by the institutionalization of a parliament, by according voting rights to a substantive part of the population, by a separation of powers and by the creation of an independent judiciary. Nevertheless, broad elite groups in both societies were opposed to democracy in any modern sense (Wright, 
1995; Hommerstad, 2014). A majority of the population was left outside the political process: all women and un-propertied men, and in the United States also slaves.

Pressures for a modern democracy with political equality emerged in parallel during the $19^{\text {th }}$ century, eliciting decisive renewal processes. But the substantive content and the pace of change differed. In part this had to do with modernization in each country going through dissimilar types of drastic crises, and in part their differences in $19^{\text {th }}$-century political development were due to the position of the public bureaucracies in the two countries - the United States had a weak bureaucracy (Fukuyama, 2014), whereas the civil service achieved a dominant position in Norway during the same period (Seip, 1968).

\subsubsection{United States}

The United States being the first modern state to establish a democratic regime, it took several decades before elite compromises shaping the constitutional culture were definitely established. Focal points in this period are the Articles of Confederation 1777/1781, replaced by the Constitution of 1789, the complementary Bill of Rights two years later and the establishment of judicial review by the Supreme Court in 1803 (Wright, 1995; Wood, 2009). The establishment of the Constitution became an elite compromise out of the necessity to coordinate separate states with widely differing interests against the colonial power and later integrate them under a federal umbrella (Higley \& Burton, 2006, p. 112f.). At the same time, a deep and principled disagreement over the centralization and decentralization of power remained unresolved and was later manifested in several heated conflicts over power relations between the states and the federal government (Wright, 1995; Wood, 2009). Even so, the basic structure of the political institutions was secured from the early $19^{\text {th }}$ century. The growing centrality of the Supreme Court in that period significantly contributed to the stability of the compromise (Wright, 1995, p. 302; Wood, 2009, pp. 433ff.).

An implicit part of the compromise, the question of slavery and its blatant discrepancy with the Bill of Rights, became increasingly conflict-ridden in the following decades. The Constitution remained open in regard to the citizen rights of the black population; the Southern states set as a precondition for joining the union that slavery be left untouched, while it was gradually prohibited in the North. The uneasy relationship was formalized by federal legislation as the Missouri Compromise in 1820, prohibiting slavery in the then unorganized 'Missouri Territory' (not to be confounded with the State of Missouri) of the Great Plains, while it remained in the South (Wright, 1995, pp. 275ff.). When the Missouri Compromise was overthrown by the Supreme Court in 1857, the political struggle that later led to the Civil War was released, and the compromise broke down. 


\subsubsection{Norway}

The Constitution of Norway emerged after the Kiel treaty in the wake of the Napoleonic Wars transferred Norway, then a province of Denmark, to Sweden. In the interregnum of the transference in the spring of 1814, a coalition of the Danish crown prince and Norwegian elites created the Constitution and declared Norway a sovereign state (Stråth, 2005; Dyrvik \& Feldbæk, 1996; Midgaard, 1989). A war broke out with Sweden, which claimed Norway as its possession; it was a short war that Norway was destined to lose. As a result, the Constitution was revised in the same year to conform to the political union with Sweden. It actually became more democratic than the original Constitution as the royal prerogatives of the Swedish king over Norway were restricted (Stråth, 2005, pp. 96ff.; Dyrvik \& Feldbæk, 1996, p. 162f.).

Despite Swedish supremacy in certain areas, the Constitution represented a compromise between Norwegian elite groups (Higley \& Burton, 2006, pp. 122, 143f., are ambiguous on this point). Parallel to the American case, the original impetus for the compromise was opposition to the colonizing power combined with common enlightenment ideals. At the same time the leading actors were divided in their views on the viability of Norwegian sovereignty. A group of patriots opted for full national sovereignty; a second large group saw maximal autonomy in a union with Sweden as the only realistic path; and the Danish crown prince, elected as Norwegian king, may have had plans of restoring the union between Denmark and Norway. The final compromise was the acceptance of the revised Constitution, within a relatively loose political union with Sweden that would last until 1905. For a century the existence of a separate constitution within the union became a bulwark for Norwegian autonomy against Swedish supremacy. Norwegian semi-sovereignty was reinforced by the establishment of representative local democracy in 1837 (Sejersted, 2001, pp. 207ff.; Lauten, 2014; Midgaard, 1989). Moreover a large part of the leading elite members were civil servants trained in Denmark, without close connections to the Swedish administration. This regime, lasting for seven decades, was later termed the 'Civil Servant State' (Seip, 1963; Slagstad, 1998).

\subsection{Processes of Regime Stability and Change}

Parallel extensions of civil and political rights in the United States and Norway took different paths, not least due to different degrees of flexibility in regard to changes in their respective constitutions. Politically induced changes in the American Constitution take place very infrequently; the wording of the Constitution of 1787 remains untouched, and amendments have to be ratified by three-fourths of the states. The main source of changes in the constitutional culture does not reside in revisions of the Constitution but in its interpretation and application to new areas by 
the Supreme Court. Hence, judicial expertise plays a prominent role in shaping the political regime.

In Norway the Constitution has undergone more than 300 adjustments over the last 200 years; until 2014 about two-thirds of the original articles had been reformulated (Hoelseth, 2014). That year saw a thorough revision, inter alia to include core articles on human rights (Kierulf, 2014). A revision of the Constitution requires a majority of two-thirds of votes in parliament and cannot be put to final vote before the following parliamentary period after it has been introduced; thus the Norwegian constitution is stable and supple at the same time (Sejersted, 2014; Smith, 2003, pp. 29-30). The Supreme Court of Norway has a different position from that of its American counterpart; even so, judicial review has a certain place, partly due to inspiration from the United States (Slagstad, 1995) and was included in the Constitution in 2014. Yet, changes in the constitutional culture are mainly driven by parliamentary processes.

\subsubsection{Regime Stability and Change in the United States}

When the original elite compromise settled by the Constitution broke down with the outbreak of the Civil War, it took more than a decade before the compromise was re-established, based on the ratification of the Reconstruction Amendments - the $13^{\text {th }}$ abolishing slavery, the $14^{\text {th }}$ guaranteeing legal protection and citizen rights to all adult citizens and the $15^{\text {th }}$ according the right to vote to all men. Against ferocious opposition from the South, these changes were forced through by the victorious party. A renewed elite settlement was finally established with the Compromise of 1877, over the deadlocked presidential election of the preceding year, along with the withdrawal of Northern troops from the South (Foner, 1988). The new compromise implied, on one hand, that the extension of citizenship was broadly democratized as the $15^{\text {th }}$ Amendment prohibited denial or abridgement of the (male) right to vote 'on account of race, color, or previous condition of servitude'. On the other hand, informally the South was accorded a sort of 'home rule' due to loopholes in the 14th and 15th amendments, which allowed a crude interpretation of the political and social rights of citizens, agreed upon by the Supreme Court, by means of a series of 'tests' to be passed in order to vote. Social discrimination continued, and the political rights of the black population were effectively undermined (ibid.).

An important outcome of the processes leading up to the Civil War and Reconstruction was the establishment of a relatively stable system of political parties. In various loose constellations political parties had already existed since the first decade after independence. Shortly before the Civil War more lasting foundations for the party system were laid down, and what were to be the two main parties were instituted in the 'Third Party System' - thereby creating a more viable framework for the agreement to disagree. The introduction of male franchise had as a natural sequel the emergence of a growing movement for women's right to vote, which was 
introduced gradually in some states and fully recognized by the $19^{\text {th }}$ Amendment in 1920.

The crucial position of the US Supreme Court is illustrated by the series of decisions reinforcing racial discrimination. Segregation was confirmed by the Supreme Court in United States v. Reese (1876) on restrictions of voting rights and in Plessey v. Ferguson (1896) on the 'separate but equal' doctrine (Morison et al., 1980, vol. 2, p. 274; Fishel, 1996). A growing opposition against formalized race discrimination was building in the following decades, which became constitutionally effective in the mid-1950s, when the Supreme Court verdict in Brown v. Board of Education (1954) banned racial segregation in schools. That signalled a new breakthrough for the reinforcement of citizen rights by the Civil Rights Act in 1964 and the Voting Rights Act of 1965 in the wake of the Civil Rights Movement. These acts did not change citizens' formal constitutional rights, but they made non-discriminatory intervention in non-political agencies enforceable in the federal legal system, concerning both race and gender.

Another type of compromise is linked to the interplay of politics and economic and social interests. The Progressive Era of the early $20^{\text {th }}$ century saw a series of modernizing reforms at all levels of society, 'shaping the modern state' (Freidel \& Brinkley, 1982, p. 93), albeit still in statu nascendi. Many of the initiatives had their base in state, municipal and individual initiatives concerning education, municipal administration, health care and family policies. Others strengthened the federal level through crucial regulations of the economy (Morison et al., 1980, vol. 2) - among these the adoption and later reinforcement of antitrust legislation to secure free enterprise, the establishment of the Federal Reserve and the establishment of federal income tax by the $16^{\text {th }}$ Amendment. Given the subsequent stability of these reforms, they may be seen as an extension of the initial elite compromise.

The core of the revisions to the American political regime is basically the consolidation of individual constitutional rights. These processes have a double face as the reinforcement of individual rights implies strengthening federal authority for setting and enforcing these rights. Constitutionally, this meant a significant increase in federal power over the states. The long-living compromise on racial inequality lost its force, and racial discrimination, albeit in no way abolished, was gradually pushed out of the open landscape of the public sphere.

\subsubsection{Regime Stability and Change in Norway}

After 1814 three all-embracing crises appeared, all connected to national sovereignty, which may be regarded as a renewal or reinforcement of the initial elite compromise (Gulbrandsen et al., 2002, p. 27; Higley \& Burton, 2006, p. 122). The first crisis had as its formal element an amendment of the Constitution in 1884, allowing members of cabinet to meet in parliament. The wider consequence of the introduction of the system of parliamentary governance was a drastic change in the power balance as the 
cabinet was made accountable to the parliament and no longer to the king (Stråth, 2005, pp. 264ff.; Hagemann, 1997, pp. 122ff.; Midgaard, 1989). The change had a double character - on one hand as an institutional transformation in the system of checks and balances, with a clear democratic element. In addition came the growth in Norwegian independence within the political union. Given that the king was Swedish, parliamentary governance meant a drastic reduction of the power position of Sweden in the union, a change that meant a boost to the Norwegian movement for full national sovereignty.

The political transformation had traumatic consequences, however, as it ended in the impeachment of prominent politicians of the old elite. A further result was the formation of stable political parties. Despite the heated conflicts leading up to the political transformation, the principle of 'agreeing to disagree' was institutionalized on a broader basis in politics (Hagemann, 1997, p. 130). Nevertheless, it took another decade and a half before general voting rights for men were introduced, in 1898, whereas universal female suffrage was instituted in 1913. Voting rights at the national level came as the result of strong social movements and after full participation in various types of local elections and referenda (ibid., pp. 204ff.; Langeland, 2014), much as in the United States.

The second crisis came with the final breakup of the union with Sweden and the establishment of a sovereign Norwegian state in 1905. This came at the end of a long-term process where the conflicts between rural and urban interests, which to a large extent coincided with attitudes towards the Swedish-Norwegian union, were tempered, and a national consensus on sovereignty developed. But only a few years later the national consensus was put to a serious test by the emergence of a radical labour movement and heated class struggles in the 1920s and 1930s (Sejersted, 2011, pp. 122ff.; Kjeldstadli, 1994). However, politically these conflicts were mitigated by the introduction of a new electoral system, where the majoritarian system was replaced by proportional representation in 1920. One intention behind the change was to contain the expansion of the labour movement (Danielsen, 1984, p. 19), but it also eased the achievement of compromises within the political system despite class conflict.

A third agreement of far-reaching consequences was settled by the end of the Second World War. During the German occupation from 1940 to 1945 elite members of different political persuasion shared traumatic experiences in concentration camps. Out of these experiences emerged new political networks and a significant reciprocity of confidence across political demarcation lines. The class struggles of the 1920s and 1930s made room for a new elite consensus in the postwar period (Lange, 1998). Even with Labour Party dominance for more than two decades, and despite confrontations, political relationships between the left and right remained largely cooperative (Sejersted, 2011, pp. 296ff.). The Labour Party accepted private property rights and made several attempts at creating institutions for employer-employee cooperation, ending in a compromise in regard to participation in working life starting in the $1970 \mathrm{~s}$ (Falkum, 2015; Engelstad, 2015). In the field of security policies, former neutrality 
was given up. Bipartisan support emerged for the anchoring of Norway in the Western bloc via membership in NATO and inclusion in the Marshall plan (Lange, 1998, pp. 136ff.). As a long-term result, the postwar consensus opened up for the erection of the Norwegian welfare state.

\subsection{Secondary Elite Compromises}

If the original elite settlement is not self-reinforcing, and may even be threatened by breakdown, how is it nevertheless maintained? One possibility is that the constitutional culture is complemented by the institutionalization of secondary elite compromises in specific social spheres - working life, religion, welfare state provisions - relevant to policies at the national level (Engelstad et al., 1999; Gulbrandsen et al., 2002). Compromises may be settled between opposing groups in a given field, such as employers and employees in the labour market (Dahrendorf, 1959), or between sector leaders and political actors at the overarching state/federal level - or both at the same time. Important actors in secondary elite compromises are social movements. Even if they mobilize broad groups of adherents, they are also dependent on organizational leadership, which in given instances entails sector elites in the sense specified above.

\subsubsection{The United States}

The United States may be regarded as a cradle of social and political movements, hosting long-term commitments to a single cause or a specific set of policies beginning with the liberation movement for independence in the 1770s. Typical for the United States is that such movements do not constitute unitary associations but rather consist of several, often scattered, groups and organizations joining forces at crucial points. Partly they have common or related aims, while at the same time they are divided by differences in strategies and short-term goals. There is also a clear tendency for movements towards specific goals to be opposed by counter-movements.

Through American political history a chain of dominating social movements stand prominently, with others, less visible, flowing in parallel streams. From Independence until the end of the Civil War the abolitionist movement was dominant (Wright, 1996, pp. 432ff.; Morison et al., 1980, vol. 1, pp. 499ff.). Starting in the late 1860s the suffrage movement, not least inspired by abolitionism, took centre stage, up to the interwar period (Scott, 1982). Industrialization and later economic crisis brought the labour movement to the fore in America (Dubofsky \& Dulles, 2010) until the mid-1950s, when the Civil Rights Movement took a prominent role (Weisbrot, 1991). In the aftermath of the 1960s, the picture is more blurred, with many parallel 'new social movements', none of which have a similar dominant character (Oberschall, 1993). Many have a double character: on one hand they are single-issue movements; if on the other their 
ambitions are universal, they aim at changing the interpretation of citizenship - in other words, the constitutional culture. In the United States, this implies that they target decision-making at the level of the federal state.

Among these the labour movement has held a somewhat ambiguous position as it has promoted workers' rights in bargaining with employers, acted as an interest representative in policies of welfare and social security and partly also advocated more general aims of social change. Likewise, the neo-feminist movement from the 1960s on is a special type of single-issue movement, but clearly with broad implications. Its goals stretch from reorienting the interpretation of civil rights connected to body and reproduction, to gender discrimination covered in the Civil Rights Act of 1964 along with race, to struggles for reform and the reinterpretation of intimate relationships between women and men. The pro- and corresponding anti-abortion movements both raise profound political questions: what constitutes a person, under which conditions does an organism acquire rights and what is the extension of these rights?

Other significant movements are directed at federal policies but are limited to one specific policy field. Farmers' movements give a prominent example. A particular case is the temperance movement, which for a period won an extreme victory by adding the $18^{\text {th }}$ Amendment to the Constitution, prohibiting commercial manufacture and distribution of alcohol (Gusfield, 1963). But prohibition soon turned out to be a failure and was repealed by a new amendment (21 2 ). From the mid-1960s the 'new' social movements gained momentum from the Civil Rights Movement but with different orientations: anti-war movements, with resistance against the Vietnam War as the most prominent case; gay movements, consumer movements and environmental movements are other examples.

To what degree have these movements engendered secondary elite compromises? Clearly, the abolitionist, suffrage and civil rights movements have been successful, but it hardly makes sense to characterize them as secondary compromises as they go to the core of what constitutes citizenship and are thus related to the original compromise. The institutionalization of policies for affirmative action, based in the Civil Rights Act of 1964, may be seen as a secondary compromise, within the legal system as well as in innumerable local versions. Even if limited, the institutionalization of collective bargaining rights may also be regarded as a secondary compromise. For the other 'new' movements the situation is less clear; their immediate aims are mainly directed at specific political decisions - stop this law, prevent this pipeline, end this war which are dependent upon the compromise of agreement to disagree but which in themselves are not constitutive compromises. For the most recent movements, the Tea Party and the Occupy Wall Street movements, the idea of compromise seems utterly irrelevant, at worst a sign of moral or patriotic deficiency.

A different type of compromise is the gigantic set of programmes adopted during the New Deal (1932-1938) as a response to the economic crisis after 1929 bearing many characteristics of a secondary elite compromise. Reorganization in the financial sector, the creation of a housing policy, legislation on social security and labour 
market policies giving jobs to millions of people were core elements of the reforms. The overarching pattern of the programmes '... can be summarized in a single word: security ... Job security, life-cycle security, financial security, market security' (Kennedy, 1999, p. 365). The Social Security Act of 1935 instituted new forms of federal social provisions (DeWitt, 2010). The National Labor Relations Board (NLRB), established 1933-35, had as one of its aims to handle employment disputes and secure collective bargaining rights. The Fair Labor Standards Act of 1938 introduced among other things the 40-hour work week and a minimum wage. In parallel, membership in trade unions was steadily increasing in the 1930s and up to the 1950s (Domhoff, 2013).

In the institutional sense, the New Deal may be regarded as three separate elite compromises. One is based in the restructuring of the financial sector, with salient consequences for housing policies. A second is the structuring of employment relations and the functioning of the National Board of Labor Relations. And a third is the consolidation and expansion of Social Security programmes. The active federal state was a precondition for establishing these ambitious policies. They introduced a form of mixed economy that did not break with the basic logic of capitalism; the point was not 'socialization' but rather regulating competition and channelling flows of private capital, thus settling a compromise between capital and labour: '[E]verywhere the objective was the same: to create a uniquely American system of relatively riskless capitalism' (Kennedy, 1999, p. 371). The New Deal decisively changed the institutional landscape. At the same time it was a sweeping political success, leading to the dominance of the Democratic Party for decades afterwards.

As with all compromises, these became arenas of power struggles. Reconfiguration has taken place by stagnation, retrenchment or expansion. From 1938, no more reform programmes were initiated by the Roosevelt administration. This may be due to its limited economic success: economic growth rates were falling, and voter support was in decline. But there are other important factors - was it really a compromise or only a provisional victory over adversaries? A stable compromise may well start with the sceptics being defeated, but in the long run they must change attitudes and accept the result. This was hardly the case with the New Deal. After 1938 further developments of reform programmes were blocked in Congress by an informal but strong coalition of Republicans and conservative Southern Democrats (Patterson, 1967; Morison et al., 1980, vol. 2, p. 523). This coalition was operative until the early 1960 s.

In working life reforms were later pushed back. The Taft-Hartley Act of 1947 stripped the National Labor Relations Board of many of its functions and deemed illegal a series of forms of conflict (Dubovsky \& Dulles, 2010, pp. 325ff.). A few years later trade union membership started declining, from more than a third of the workforce in the early 1950s to slightly above ten percent in 2010 (ibid., pp. 344ff.; Domhoff, 2013). In part this is due to the restructuring of the economy and a massive reduction of traditional jobs in manufacturing, but also to active resistance among employers. 
In the area of social security, expansion was the main picture until the mid-1970s, concerning benefits as well as coverage (DeWitt, 2010). Ideals from the New Deal became the backbone of the politics of the Great Society during the 1960s. Under the heading of War on Poverty, programmes on education and health were introduced along with relatively generous increases in welfare provisions. Most central were the Medicaid and Medicare programmes, the former securing basic medical treatment for people with low incomes and the latter targeted to persons aged 65 and over. They have remained quite robust over time (Béland, Howard, \& Morgan, 2014). A period of selective retrenchment began in the late 1970s, under the heading of neoliberalism; resistance to welfare state provisions increased, leading to partial contractions in the 1990s (DeWitt, 2010). Bipartisan support for the compromise has slowly withered away over the last three decades, indicated early on by the rejection of universal health care coverage in the early 1990s. The present attempts to dismantle the Affordable Care Act of 2010 bear witness of continued elite conflict over the American version of the welfare state.

Even if cutbacks have been made in welfare policies, this in no way means that these policies are being dismantled. Paul Pierson (2000) has argued that retrenchments meet much stronger resistance than the establishment of new forms of provisions. Discussion and critique of his theory have pointed out that the stability is less secure than assumed by Pierson (Levy, 2010), not least because significant parts of welfare provisions are anchored in private sources. But even under Republican presidents the programmes have been expanded (ibid.). Social Security policies will hardly be abolished, even if the balance between public and private elements is continuously in flux (Béland, Howard, \& Morgan, 2014). This is also difficult for ideological reasons. A striking example of the ambiguity in welfare policies was expressed by President Reagan, otherwise famous for his adherence to neoliberalism, when he signed a bill revising the funding of Social Security in 1983: 'This bill demonstrates for all time our nation's ironclad commitment to Social Security' (DeWitt, 2010). If some regulations of working life remain, and Social Security is after all not threatened despite retreats and continued resistance from parts of the elites, a lasting legacy of the New Deal is 'a set of institutional arrangements that constituted a more coherent pattern than is dreamt of in many philosophies', as emphasized by David Kennedy (1999, p. 365), albeit in a modest version.

\subsubsection{Norway}

Protest movements are an important part of Norway's political history, dating back to the $18^{\text {th }}$ century. Anti-tax rebellions among farmers regularly took place as did protests against the discrimination of religious sects and against the monopoly of the State Church. These movements culminated around 1850, with a nationwide mobilization of workers in favour of universal suffrage for men (Bjørklund, 1970; Furseth, 2002), 
but were met by violent reactions from political authorities. Starting in the mid-1850s, however, along with the emergence of a broader national consciousness, new forms of social movements emerged. They were better adjusted to the ongoing political system and had as their goals a combination of a national-democratic development and single-issue-based mobilization.

From the 1870s on, movements pressing for voting rights gained support - in the first round male franchise, whereas the feminist movement took hold somewhat later and with a broader set of goals linked to women's family rights as well as rights of free choice of education and occupation (Hagemann, 1997). Most important besides these movements were the so-called 'countercultures', a label covering broad movements of religious revival, temperance and strivings for a New Norse language separate from established Danish linguistic norms (Rokkan, 1970). Women also played a prominent role in these movements, something that eased the relatively early introduction of full franchise for women in 1913 (Hagemann, 1997, pp. 160ff.).

A wave of revival movements in the second half of the $19^{\text {th }}$ century succeeded in breaking the monopoly of the state church, and in 1908 a separate divinity school was established outside the state university, which soon educated the majority of the ministers of the Norwegian state church. As part of the national mobilization of the $19^{\text {th }}$ century, the New Norse language was instituted as a second official language, on a par with the dominating language shaped during the political union with Denmark. In these cases, the strategy was that of conquering the state apparatus within one specific field, thereby institutionalizing policies and strengthening democratic legitimacy for minority groups. The temperance movement, like its US counterpart, was initially very successful but then lost out (Bjørklund, 2005). However a compromise was settled by accepting state monopoly on the distribution of wine and liquor (Hamran \& Myrvang, 1998, p. 69ff). Common to these counter-cultural movements was that they organized themselves on a national basis with local chapters and a national headquarters. Not only did they operate as pressure groups but also as organizational actors, with the main strategy of conquering the state apparatus in their field, extending political rights and democratic legitimacy to minorities or groups with low social status.

Having exhausted their potential or reached their original goals, the countercultural movements are of moderate significance today. But their mode of operation is continued by more recent social movements (Mjøset, this volume), albeit in a more decentralized way. Most successful is the feminist movement, a branch of which in Norway goes under the label of State Feminism. This notion points to the role of the state in promoting gender equality - not only by prohibiting discrimination (the American case served as a powerful example) but also by actively promoting women's interests linked to family policies and health care as well as to working life (Hernes, 1987; Teigen \& Skjeie, 2017). Besides neo-feminism, environmentalism is the most visible among the 'new' social movements, consisting of a broad set of organizations from national bodies to special lobby groups. In line with the countercultures, the new movements have established close contacts with the state while at the same 
time retaining their political independence. They exert considerable influence by functioning as consultants as well as oppositional counterparts to state agencies (Kjellman, 2007). A different type of protest is the anti-EU movement, which defeated the elites in the referenda both in 1972 and 1994, thus keeping Norway outside the European Union (Sejersted, 2011, p. 476f.). This movement represents a continuation of the national-democratic strivings for national sovereignty of the $19^{\text {th }}$ century, where defence of the Constitution played a crucial role. The subsequent elite compromise was Norwegian membership in the European Economic Area, including the country into the EU inner market but without political membership rights.

Less of a single-issue movement is the labour movement, the other main part of the movement landscape. Due to a close relationship between the Labour Party and the trade union federation LO, the labour movement has from the beginning of the $20^{\text {th }}$ century had a broad anchorage in politics. In 1935 the Labour Party came to power, which marked the beginning of social democratic hegemony. It also meant the beginning of close connections between the labour movement and the state (Kjeldstadli, 1994, pp. 212ff.; Sejersted, 2011, pp. 301ff.). Whereas the New Deal in the US became a drastic but short period of reforms in the 1930s, the opposite was the case in Norway. In the short term, the change of power did not have strong effects; the main innovation of the mid-1930s was the settlement of the Basic Agreement between the national associations of employers and trade union federations, having taken place some months before (Falkum, 2015; Seip, this volume). The agreement was a compromise guaranteeing the rights of trade union officers within enterprises and at the same time a formal recognition of employer prerogatives. Living in a small country with an economy strongly exposed to the world market gave Norwegians a strong impulse to seek social cooperation across class boundaries (Moene, 2013), resulting in a high degree of social trust.

The combination of political power and the Basic Agreement had long-term effects on the relationships between the labour market parties. For decades wage bargaining has involved nationwide associations of employers and employees. The state plays a role as an active regulator as well as facilitator, sometimes even as an active participant creating compromises in the negotiations. Employees in large and medium sized (i.e. by international standards quite small) joint-stock companies have the right to elect representatives to the board of directors, and in virtually all companies management and workers participate on an equal footing in Health and Security Committees, exerting considerable power (Trygstad \& Alsos, this volume; for a comparative discussion see Engelstad, 2004). That these regulations are a part of viable compromises was amply demonstrated in a survey among Norwegian elites, where 80 percent of CEOs and board chairs in the largest enterprises expressed support for the Norwegian labour market regime (Gulbrandsen et al., 2002, pp. 169ff.).

The cooperative relationships between the labour market parties also paved the way for a gradual extension of the largely universalist welfare state. Schools and universities, health care institutions and nursing homes are basically public 
institutions, albeit with some elements privately owned and run (Trætteberg, this volume). A common assumption is that the volume of welfare state services is linked to the prevalence of leftist parties holding political power. However, support from employers is of equal significance (Huber \& Stephens, 2005). Employers have a general interest in a well-functioning welfare state; if they have problems supporting it, it is no so much a result of direct resistance as of collective action problems (Gulbrandsen \& Engelstad, 2005; Gulbrandsen, this volume). A long-term effect of the Basic Agreement is that the employer and employee federations exert significant influence on a wide range of issues outside the labour market, such as health policies, education policies and pension systems (Hagelund \& Pedersen, 2015). Welfare state issues are the top preferences of the electorate and have remained so since the mid1980s (Aardal, 2003, p. 16). Since the introduction of the general welfare state system, several adjustments have been made, some expansive, others of a more contractive character. But talking about welfare state retrenchment in Norway does not make sense.

\subsection{Varieties of Elite Compromises}

Three theoretical postulates were stated at the beginning of the present chapter as a reformulation and broadening of the basic assumption of elite compromises as a precondition for the emergence of democracy: (i) Initial elite compromises must be confirmed, renewed and partly even drastically changed to meet the demands of a developing democratic society. (ii) In this process, the original settlement is reinforced by secondary elite compromises. (iii) Elite settlements are more precisely understood when formulated in terms of institutional change.

Despite noteworthy similarities in the early phase, crucial differences between the United States and Norway have been pointed out. In the United States the renewal of the initial elite compromise became dramatic. Remarkably, after the Civil War substantive changes in the structure of political institutions were not made. Renewal became foremost a question of reinterpretation and the ensuing displacement of power from states to federal authorities. The extension of the franchise to new groups was an unavoidable part of democratization and elicited overwhelming social conflict. The most drastic challenge to constitutional culture was the inclusion of the non-white population as citizens in the full sense, even if it was countered by new discriminatory measures in the South. The Progressive Era saw important institutional changes in the relationship between politics and economy, which mostly meant changes in constitutional culture in a form that did not break with ideas of free enterprise. Thus, the original elite compromise was and still is living on in the United States, albeit in a broader and more developed form. The Constitution is the main political glue, and the Supreme Court its guardian, notwithstanding enormous social changes. 
In Norway, the process of democratization was less dramatic while at the same time characterized by more flexibility. Changes in the Constitution and constitutional culture were substantial. In addition to the necessary extensions of the franchise, decisive changes in the governance system were implemented: first by the introduction of the parliamentary system, limiting the power of the king, and second by reform of the electoral system, where the first-past-the post system was replaced by proportional representation. In addition to these transformations, the incessant minor reforms of the Constitution represent a form of flexible adjustment without invalidating its continuity over a 200-year period.

Despite important parallels in the process of democratization, differences in secondary compromises have turned out to be highly significant. Social movements played a crucial role in both countries, with the United States as inspiration for Norwegian movements; however, except for movements directly related to citizenship, differences are clearly visible. In the United States these social movements mostly aimed at and remained at the local level, or at the level of states. In Norway, movements to a large extent have had wider political targets, aiming at changes in policies at the level of the nation state, as exemplified in the language and religious movements. A curious exception from the rule is the temperance movement, which reached the top political level and then shortly after failed in both countries. Significantly, the outcome in Norway primarily was an overarching compromise on alcohol distribution, whereas alcohol policies in the United States, in a more diluted version, remained at the level of states.

In the wake of the Progressive Era, partly in contrast to it, the New Deal introduced in 1932-1933 a set of policies of unprecedented dynamism lasting for a six-year period. Its heritage still lives on, albeit in a diminished version. Parts of the New Deal reforms were durably institutionalized, most clearly in the field of social policy. Other parts of the reforms did not represent viable compromises in the long run and were to a large extent pushed back, albeit not totally abandoned. In contrast, when the Labour Party came to power in Norway in 1935, their reform programme was by far more modest. Even though inspiration from America was considerable in Norway in this area, too, subsequent developments took very different trajectories. The compromise of the Basic Agreement 1935 became a stepping stone for national federations in the labour market to evolve into powerful political actors, initiating broad policies of wage formation and working life reforms. In the next round, these also became crucial partners in the building of a comprehensive welfare state.

\subsection{Modes of Institutional Change}

A systematic interpretation in the light of institutional theory has brought a variety of elements into a coherent frame of analysis. The emphasis on institutions, in common with the elite perspective, invites analyses of group competition and the exertion of 
power. In the following a brief comparison of modes of institutional change is sketched. Given the complexity of these developments, all three sources of institutional change mentioned above (p. 368) - shocks, gradual effects and ideology - are of relevance.

Take first the assumption of changes by external shocks. In the case of the primary compromise in the United States this was relevant in the early period. The wars with Britain of the late $18^{\text {th }}$ and early $19^{\text {th }}$ centuries certainly had the character of external shocks, releasing and later consolidating Independence and the adoption of the Constitution. The Civil War, undoubtedly a shock, was not an external shock in the same sense but more of an explosion let loose by internal tensions and pressures building up over a long time. The main cause of these tensions was the implicit compromise over race in the Constitution in combination with the expansion of the United States westward and the conflicts over slavery in the new territories. Remarkably, the utterly dramatic confrontation that followed did not bring additional changes to the Constitution other than the three Reconstruction Amendments, which were more of the nature of specification of the original text than a substantive change, even if the constitutional culture was not left unaffected. Progressive reform in economic policy as well as legislation on women's franchise and later on civil rights have the same baseline: that of affirming individual constitutional rights, albeit accompanied by increased federal authority.

The secondary compromise of the New Deal, however, clearly stemmed from an external shock, and it released feverish reform activity over a period of a few years, albeit without confronting established American traditions. Even if the New Deal left some institutional footprints, many of the reform measures were subsequently toned down. Only to a limited extent did the external shock engender viable, or at least expansive, impulses.

Likewise, war opened a window of opportunity for the development of the Norwegian Constitution. In a short period the peace settlement of the Kiel treaty offered national groups the chance to draft a separate constitution for Norway. This occasion is obviously in line with the theory of path dependency, like in the United States. The war and German occupation of 1940-45 also came as an external shock, which later reinforced the spirit of cooperation in politics and working life. However, in this case the outcome was more representative of continuity as the war and the ensuing peace sped up processes already underway before the war, when the Labour Party came to power. The crises of 1884 and 1905 were of a different character. They were most of all results of long-term tensions building up over Norwegian sovereignty within the union with Sweden, resulting in drastic institutional changes with the replacement of old regimes by new ones - in the first case by introducing parliamentary rule and in the second by achieving full national sovereignty. The electoral reform of 1920 was equally a displacement resulting from tensions building up, albeit related to social class and not national interests. In parallel, secondary elite compromises in the last half of the $19^{\text {th }}$ century developed as a reflection of a complex set of tensions connected to movements springing out of conflicts between centre and 
periphery, national strivings and democratic mobilization. The strong class tensions dominant in the first decades of the $20^{\text {th }}$ century subsequently were mitigated by the Basic Agreement.

Brief as it is, this sketch presents a mixed picture. External shocks are of importance, but more clearly present in both countries is the picture of internal tensions driven by political and ideological conflict, which in critical moments may explode. In contrast, only in special cases do external shocks seem to drive viable changes - that is, as long as they do not invite new compromises. Here the difference between the long-term effects of the New Deal and the Basic Agreement offer an illustration. Given the gradual character of institutional change that emerges from this juxtaposition, crucial differences between the United States and Norway have come to the fore regarding the mechanisms developed by Thelen for gradual institutional change. Table 17.1 gives a rough summary.

Table 17.1. Dominant modes of institutional change

\begin{tabular}{llllll}
\hline & Conversion & Displacement & Layering & Drift & Addition \\
\hline United States & Yes & No & Yes $^{1}$ & Yes & No \\
Norway & No & Yes & Yes $^{2}$ & No & Yes \\
\hline
\end{tabular}

Typical of the United States is the importance of conversion, in the sense that the letters of the Constitution have remained virtually unchanged, while its interpretation and the constitutional culture have gone through great changes, partly by additional legislation, partly by reinterpretations by the Supreme Court. Conversion, however, is less typical in the Norwegian case. The corresponding process has rather been that of displacement, breaking out of political union, changes in electoral system and the transformation of balance between powers - none of which are more than weakly present in the United States. Thelen's two additional mechanisms are more complex. Layering is a mode of change that is ubiquitous and is certainly present in both countries. In the present context, however, one noticeable difference stands out - that of the social security system. The American system is layered in the sense that it represents a very complex mix of private and public arrangements, which makes it quite resilient, for better or worse. In one sense the Norwegian system is more transparent as social security is mainly a public task. However, this development goes together with a broad politicization, where strong civil society actors have a formalized influence on possible reforms. Likewise, drift is a ubiquitous phenomenon. Institutions gain or lose positions by changes in how they are supported, or put to use. One important instance of drift in the American case is the drastic reduction in labour union membership. In parallel, support for the 'old' social movements has been clearly declining in Norway, and trade union membership has shown a certain 
decrease. But in practice this is mitigated by the strong institutionalization of the policy fields that these movements still represent and sustain.

These observations also point to a type of institutional change that is not part of Thelen's taxonomy, namely the addition of new institutional arrangements to those already in existence. This is primarily due to institutional differentiation and specialization linked to the emergence of new technologies, new professions or generally new modes of thinking. The mode of institutionalization is affected by the state taking on new responsibilities and developing new policy fields, such as more comprehensive policies for social welfare or culture (Engelstad, 2017). At the same time existing institutions are affected by the emergence of new ones as they change the environment of those already in existence (Luhmann, 2013). This should be related to the concept of institutional bundling in the varieties of capitalism theory perspective (p. 367 above), where it is implicitly assumed that the two types of capitalist economies engage similar institutions but with different designs. The presentation here reveals a more complex picture, indicating that institutional differentiation affects the pattern of bundling. Even if institutional differentiation in one sense means greater stability, from a different viewpoint it may represent greater flexibility. The differences between the American and Norwegian institutional bundles indicate how secondary elite compromises develop differently in the two societies, despite similarities in their point of departure in constitutional governance and in democratic development.

\subsection{Resilience of Democracy}

In light of these observations, how has the persistence of constitutional culture in the United States been possible? A set of reasons often cited has to do with economic progress over time. Despite crises and depression, taken as a whole the American economy has been a tremendous success, not least to the benefit of the elites, who are the most powerful guardians of the system. The crucial combination of the Constitution, the position of the Supreme Court, and the power of small states within the institutions of the federal structure constitute impediments to collective action sufficiently powerful to wield off attempts at decisive changes (Dahl, 2001). In addition come central motivations. Higley and Burton (2006, p. 113) suggest a rather crude explanation: a common fear of a new civil war keeps everyone within bounds. This latent fear may be supplemented by manifest political values with strong normative power: liberty as the core concept and the Constitution as the basis of liberty. The conception of liberty driving the American Revolution was a version of negative freedom understood as minimized external authority. This is well accommodated by wide-reaching acceptance of social inequality. Together these factors shape a society that is quite tolerant of internal tensions.

There could be good reasons to assume that the flexibility of the Norwegian Constitution and constitutional culture leads to a lack of robustness, but this 
has not been the case. An extensive set of secondary elite compromises has had a significantly stabilizing effect. This is combined with the strong symbolic significance of the Constitution due to its central position in the long line of national resistance to the political union with Sweden throughout the $19^{\text {th }}$ century and to the German occupation. Moreover, broad exposure to the world market has served to ease social cooperation across class boundaries. The power of political values in Norway resides above all in ideas of equality, income security and a generous welfare state, which entails a general acceptance of collective solutions to social problems.

Undoubtedly, both systems have actual and prospective downsides. The main problem of a conservative constitutional culture is its inability to adapt to new circumstances. The United States has to a large extent been self-sufficient with economic resources, but is not so any longer. Refusal to accept this change in conditions has led to what Fukuyama (2014) has characterized as political decay - pressing institutional changes will not be made as long as there is no room for a new elite compromise. At the other end, the presently advantageous flexibility of the Norwegian system may also run into an impasse. The large network of compromises, with many actors looking after their special interests, may lead to a lack of political realism in the face of serious threats to political and economic stability. If so, flexibility turns into stalemate. Without the ability to develop broadly democratic and efficient leadership, in the worst case, both systems will face serious challenges.

\section{References}

Achen, C. H., \& Bartles, L. M. (2016). Democracy for Realists. Princeton: Princeton University Press. Bachrach, P. (1969). The Theory of Democratic Elitism. London: University of London Press.

Bjørklund, O. (1970). Marcus Thrane - sosialistleder i et u-land. Oslo: Tiden.

Bjørklund, T. (2005). Hundre år med folkeavstemninger: Norge og Norden 1905-2005. Oslo: Universitetsforlaget.

Dahl, R. A. (1989). Democracy and its Critics. Berkeley: University of California Press.

Dahl, R. A. (1999). Political Culture and Economic Development. In F. Engelstad \& R. Kalleberg (Eds.), Social Time and Social Change. Oslo: Scandinavian University Press.

Dahl, R. A. (2001). How Democratic is the American Constitution? New Haven: Yale University Press.

Dahrendorf, R. (1959). Class and Class Conflict in Industrial Society. Palo Alto: Stanford University Press.

Danielsen, R. (1984). Borgerlig oppdemmingspolitikk 1918-1940. Høyres historie 2. Oslo: Cappelen.

DeWitt, L. (2010) The Development of Social Security in America. Social Security Bulletin, 70(3). Retrieved from: https://www.ssa.gov/policy/docs/ssb/v70n3/v70n3p1.html

Domhoff, G. W. (2013). Who Rules America? The Rise and Fall of Labor Unions In The U.S. Retrieved from: http://www2.ucsc.edu/whorulesamerica/power/history_of_labor_unions.html_ [restricted access]

Dubofsky, M., \& Dulles, F. R. (2014). Labor in America: A History. $8^{\text {th }}$ edition. New York: Wiley. Economist Democracy Index (2016). Retrieved from: https://www.eiu.com/public/topical_report. aspx?campaignid=Democracylndex2016. 
Engelstad, F. (2017). A Power Elite in the Cultural Field. A Story of Norwegian Neo-Corporatism. International Journal of Cultural Policy, 23(5), 527-544.

Engelstad, F. (2004). Democracy at Work? Does Democracy in Working Life Make Sense in the $21^{\text {st }}$ Century? In F. Engelstad \& Ø. Østerud (Eds.), Power and Democracy. Critical Interventions. Aldershot: Ashgate.

Engelstad, F., Gulbrandsen, T., \& Østerud, Ø. (1999). Elite Compromises in a Stable Democracy: The Case of Norway. Paper presented to the Annual Meeting of the American Political Science Association, Atlanta.

Engelstad, F., \& Hagelund, A. (2015). Introduction: Institutional Change in Neo-Corporatist Society. In F. Engelstad \& A. Hagelund (Eds.), Cooperation and Conflict the Nordic Way. Work, Welfare, and Institutional Change in Scandinavia. London, Warsaw: De Gruyter Open.

Falkum, E. (2015). Institutionalization and Dynamic Change of Institutions - The Basic Agreement and Tripartite Structure in Norway. In F. Engelstad \& A. Hagelund (Eds.), Cooperation and Conflict the Nordic Way. Work, Welfare, and Institutional Change in Scandinavia. London, Warsaw: De Gruyter Open.

Field, G. L., \& Higley, J. (1980). Elitism. London: Routledge.

Foner, E. (1988). Reconstruction. America's Unfinished Revolution 1863-1877. New York: Harper \& Row.

Fishel, L. (1996) The African-American Experience. In C.W. Calhoun, (Ed.), The Gilded Age. Essays on the Origin of Modern America (pp. 137-161). Wilmington: SR Books.

Freidel, F. \& Brinkley, A. (1982). America in the Twentieth Century. 5. ed. New York: Alfred A. Knopf.

Frydenlund, B. (2014). Før Max Weber. Private og offentlige oppfatninger av politisk skikkethet $i$ Norge og USA for 200 år siden. In N.R. Langeland (Ed.), Politisk kompetanse. Grunnlovas borger 1814-2014, (pp. 27-58). Oslo: Pax.

Furseth, I. (2002). A Comparative Study of Social and Religious Movements in Norway, 1780s-1905. Lewinston: Edwin Mellen Press.

Goodin, R. E. (2004). Input Democracy. In F.Engelstad \& Ø. Østerud (Eds.), Power and Democracy. Critical Interventions. Aldershot: Ashgate.

Gulbrandsen, T., \& Engelstad, F. (2005). Elite Consensus on the Norwegian Welfare State Model. West European Politics, 28, 899-919.

Gulbrandsen. T., Engelstad, F., \& Klausen, T.B. et al. (2002). Norske makteliter. Oslo: Gyldendal Akademisk.

Gusfield, J. R. (1963). Symbolic Crusade: Status Politics and the American Temperance Movement. Urbana: University of Illinois Press.

Hall, P., \& Soskice, D. (2001). Varieties of Capitalism. New York: Oxford University Press.

Hernes, H. (1987). Welfare State and Women Power. Essays in State Feminism. Oslo: Norwegian University Press.

Habermas, J. (1996). Between Facts and Norms. Cambridge: MIT Press.

Hagemann, G. (1997). Det moderne gjennombrudd. Aschehougs Norgeshistorie, vol 9. Oslo: Aschehoug.

Hamran, O. \& Myrvang, C. (1998). Fiin gammel - Vinmonopolet 75 år. Oslo: Aschehoug.

Higley, J., Hoffman-Lange, U., Kadushin, C., \& Moore, G. (1991). Elite Integration in Stable Democracies. European Sociological Review, 7, 35-53.

Higley, J. \& Burton, M. (2006). Elite Foundations of Liberal Democracy. Lanham: Rowan and Littlefield.

Hoelseth, D. T. (2014). Endringer i Grunnloven. Retrieved from: https://lovdata.no/artikkel/ endringer_i_grunnloven/1383

Hommersrud, M. (2014). Et spørsmål om kunnskap? Politisk kompetanse og politisk deltagelse blant bøndene etter 1814. In N.R. Langeland (Ed.), Politisk kompetanse. Grunnlovas borger 1814-2014, (pp. 88-104). Oslo: Pax. 
Huber, E., \& Stephens, J. D. (2005). Welfare States and the Economy. In N. Smelser and R. Swedberg (Eds.), The Handbook of Economic Sociology. Princeton: Princeton University Press.

Huntington, S. (1991). The Third Wave. Democratization in the Late Twentieth Century. Norman: University of Oklahoma Press.

Kennedy, D. M. (1999). Freedom from Fear. The American People in Depression and War, 1929- 1945. New York: Oxford University Press.

Kierulf, A. (2014). Innenfra og utenfra - Grunnloven og menneskerettighetene. In E. Holmøyvik (Ed.), Tolkinger av Grunnlova. Om forfatningsutviklinga 1814-2014, (pp. 424-448). Oslo: Pax.

Kjeldstadli, K. (1994). Et splittet samfunn 1905-35. Aschehougs Norgeshistorie, vol. 10. Oslo: Aschehoug.

Kjellman, K. E. (2007). Mobilization and Protest in a Consensus Democracy: Social Movements, the State, and Political Opportunities in Norway. PhD thesis, Department of Sociology and Human Geography, University of Oslo.

Lange, E. (1998). Samling om felles mål 1935-1970. Aschehougs Norgeshistorie, vol. 11. Oslo: Aschehoug.

Langeland, N.R. (2014). Røystreretten som mål på politisk kompetanse. In N.R. Langeland (Ed.), Politisk kompetanse. Grunnlovas borger 1814-2014, (pp. 168-182). Oslo: Pax.

Lauten, M.D. (2014). Formannskapslovene - lokalstyrets grunnnlov. In H. Sandvik \& D. Michalsen (Eds.), Kodifikasjon og konstitusjon, (pp. 254-281). Oslo: Pax.

Lipset, S. M. (1959). Political Man. New York: Doubleday.

Luhmann, N. (2013). Theory of Society. Volume 2. Stanford: Stanford University Press.

Mahoney, J., \& Thelen, K. (2010). Explaining Institutional Change. Cambridge: Cambridge University Press.

Martin C. J. (2015). Negotiation and the Micro-Foundations of Institutional Change. In F. Engelstad \& A. Hagelund (Eds.), Cooperation and Conflict the Nordic Way. Work, Welfare, and Institutional Change in Scandinavia. London, Warsaw: De Gruyter Open.

Michels, R. ([1911] 2001). Political Parties. A Sociological Study of the Oligarchical Tendencies of Modern Democracy. Kitchener: Bartoche Books.

Midgaard. J. (1989). A Brief History of Norway. Vero Beach: Arthur Vanous Co.

Moene, K. (2013). Scandinavian Equality: A Prime Example of Protection without Protectionism. In J. E. Stiglitz \& M. Kaldor (Eds.), The Quest for Security: Protection Without Protectionism and the Challenge of Global Governance. New York: Columbia University Press.

Moore, B. (1966). The Origins of Dictatorship and Democracy. Boston: Beacon Press.

Morison, S. E., Commager, H. S., \& Leuchtenburg, W. L. (1980). The Growth of the American Republic. Vol. 1 \& 2. Oxford: Oxford University Press.

Mosca, G. (1939). The Ruling Class. New York: McGraw Hill.

O’Donnell, G., \& Schmitter, P. (1986). Transitions from Authoritarian Rule. Baltimore: Johns Hopkins University Press.

Pareto, V. (1991). The Rise and Fall of Elites. New Brunswick: Transaction.

Patterson. J. T. (1967). Congressional Conservatism and the New Deal. Lexington: University Press of Kentucky.

Pierson, P. (2004). Politics in Time. Princeton: Princeton University Press.

Putnam, R. (1993). What Makes Democracy Work? Princeton: Princeton University Press.

Rokkan, S. (1970). Citizens Elections Parties. Oslo: Universitetsforlaget.

Schmidt, V. (2008). Discursive Institutionalism: The Explanatory Power of Ideas and Discourse. Annual Review of Political Science, 11, 303-326.

Scott, A. F., \& Scott, A. M. (1982). One Half of the People. The Fight for Woman Suffrage. Urbana: University of Illinois Press.

Scott, R. (2008). Institutions and Organizations. Thousand Oaks: Sage. 
Seip, J.A. (1968). «Det norske system» i den økonomiske liberalismens klassiske tid (1850-1870). In J.A. Seip, Tanke og handling i norsk historie, (pp. 22-71). Oslo: Gyldendal.

Sejersted, F. (2001). Den vanskelige frihet. Norge 1814-1850. Oslo: Pax.

Sejersted, F. (2011). The Age of Social Democracy. Princeton: Princeton University Press.

Sejersted, F. (2014). Det elastiske panser. Om utviklingen av den norske statsforfatningen 1814-2014. In E. Holmøyvik (Ed.), Tolkinger av Grunnlova. Om forfatningsutviklinga 1814-2014, (pp. 35-109). Oslo: Pax.

Slagstad, R. (1995). The Breakthrough of Judical Review in the Norwegian System. In E. Smith (Ed.), Constitutional Justice under Old Constitutions. The Hague: Kluwer.

Slagstad, R. (1998). De nasjonale strateger. Oslo: Pax.

Smith, E. (2003). The Constitution Between Politics and Law. In E. Smith (Ed.), The Constitution as an Instrument of Change. Stockholm: SNS förlag.

Stråth, B. (2005). Union og demokrati. Dei sameinte rika Noreg-Sverige 1814-1905. Oslo: Pax.

Syvertsen, T., Enli, G., Mjøs, O.J., \& Moe, H. (2014). The Media Welfare State. Ann Arbor: University of Michigan Press.

Teigen, M., \& Skjeie, H. G. (2017). The Nordic Gender Equality Model. In O. Knudsen (Ed.), The Nordic Models in Political Science. Challenged, but Still Viable? (125-147). Bergen: Fagbokforlaget.

Thelen, K. (2004). How Institutions Evolve. Cambridge: Cambridge University Press.

Thelen, K. (2012). Beyond Comparative Statics: Historical Institutional Approaches to Stability and Change in the Political Economy of Labor. In G. Morgan, J.L. Campbell, C. Crouch, O.K. Pedersen, \& R. Whitley (Eds.), The Oxford Handbook of Comparative Institutional Analysis. Oxford: Oxford University Press.

Thelen, K. (2014). Varieties of Liberalization and the New Politics of Solidarity. Cambridge: Cambridge University Press.

Weisbrot, R. (1990). Freedom Bound. America's Civil Rights Movement. New York: Penguin. Williamson, O. (1975). Markets and Hierarchies. New York: The Free Press.

Wood, G. S. (2009). Empire of Liberty. A History of the Early Republic, 1789-1815. Oxford: Oxford University Press.

Wright, E. (1995). An Empire for Liberty. Cambridge: Blackwell. 